\title{
PAY AND OFFER OF BENEFITS AS SIGNIFICANT DETERMINANTS OF JOB SATISFACTION - A CASE STUDY IN THE CZECH REPUBLIC
}

\author{
Marcela Sokolová, Hana Mohelská, Václav Zubr
}

\section{Introduction}

Human resources have long been the most essential factor that affects the performance of an organization, its organizational culture or its innovation processes. They are more or less connected with everything that is going on within the organization, but they are also the key players in relation to the organization's surroundings, communicating with customers, suppliers and other relevant partners and institutions (Šoltés \& Gavurová, 2014). Human resources form an element of each system and influence it significantly, not only through their abilities and skills, but also through their attitudes and emotions. Emotions are an important factor that influence the performance of employees as well as affect their job satisfaction or dissatisfaction. They are one of the significant components of emotions, whether in the positive or negative sense of the word.

Classic definitions describe job satisfaction as a positive emotional response and experience resulting from the evaluation of one's work (Locke, 1976; Pavelka et al., 2014). The level of job satisfaction is made up of internal and external satisfaction (Ryan \& Dezi, 2000). Typically, internal satisfaction is formed by success, responsibility or recognition, while external satisfaction is formed by pay and other compensation, relationships with co-workers and working conditions. Job satisfaction impacts work performance, and dissatisfaction can be the cause of labour turnover, absenteeism and lead to associated costs (e.g. Judge et al., 2001). Moreover, job satisfaction is related to one's overall life satisfaction (Drobnič et al., 2010; Judge \& Watanabe, 1993).
A number of studies were conducted in non-Western cultures over the last decade (Borooah, 2009; Eskildsen et al., 2010; Lange, 2009). There are studies from Taiwan (e.g. Chen \& Silverthorne, 2008) and China (e.g. Liu et al., 2008), as well as from Russia (Linz, 2003). However, only little is known about the factors influencing job satisfaction in the postcommunist countries of Central and Eastern Europe, including the Czech Republic.

The first empirical data examining job satisfaction in the Czech Republic have been available since 1997 from the International Social Survey Programme (hereinafter referred to as "ISSP") that was also focused on, within the framework of one module, work orientation (working conditions, job characteristics, subjective experience of work, etc.). Using these data and the results of other research, several studies have been published (Medgyesi \& Robert, 2003; Večerník, 2003; Franěk \& Večeřa, 2008; Franěk et al., 2014) that show that the level of job satisfaction in the countries of Central and Eastern Europe was relatively low in comparison to the values of job satisfaction in the countries of Western and Northern Europe. The Czech Republic ranked among those states with the lowest satisfaction.

As mentioned above, there are many components affecting job satisfaction including, inter alia, the possibility of career growth and further professional development, working conditions and the actual work; pay and fringe benefits are also a very significant component. (Mohelská \& Sokolová, 2015; Mohelská \& Sokolová, 2011)

The aim of this study is to analyse how the level of pay and the offer of benefits determine job satisfaction in the Czech Republic. 


\section{Research Objective and Methodology}

The presented study examines how the level of pay and the offer of benefits determine job satisfaction in the Czech Republic.

\section{Subject-matter of examination}

The aim of this study it to answer the research question, whether there is a correlation between the level of pay and fringe benefits on the one hand and overall job satisfaction on the other, or with satisfaction with pay and fringe benefits.

To determine the development of the level of pay and fringe benefits, the available official data of the Czech Statistical Office are primarily used (CZSO, 2015), which concern the development of the level of pay and fringe benefits. Data mining was carried out in this area and the key trends in this area can be ascertained.

To determine the level of job satisfaction, the same study was conducted twice (in 2013 and 2015). It was conducted as a questionnaire survey - the Czech version of the "Job Satisfaction Questionnaire" (Spector, 1985; Spector, 1997). Obtained data were used for the purpose of this study with attention being focused on the analysis of overall job satisfaction and two determinants, pay and fringe benefits.

\section{Sample of respondents}

The aim of the project was to create a sample of employees from various branches from both the profit and non-profit sectors. Since a crosssectional sample could not be obtained, the data were collected through cooperation with distance learning university students. The fact that these students worked in various types of organizations in at least three regions of the Czech Republic was taken advantage of.

The data used in this study were collected in January and February 2013 and then again in the same months of 2015. Students in distance learning bachelor's degree programs were asked in certain subjects at the Faculty of Informatics and Management at the University of Hradec Králové to have their work colleagues complete the questionnaire. Typically, each student collected about 15 questionnaires. Altogether, 1,950 and 1,547 respondents respectively participated in the study. However, 174 and 77 questionnaires respectively were excluded from the sample due to various errors and missing values. Respondents are described below, in the chapter entitled Results.

Statistical analyses were performed using Statistica 8 software.

\section{Questionnaire}

The questionnaire included four sections. Three demographic questions were in the first part: gender, age and the level of education of the respondent. The second part included five questions concerning characteristics of the organization in which the respondent worked: ownership of the organization (Czech owner, foreign owner, international corporation or public/governmental organization), size of the organization (up to 50 employees, up to 250 employees, up to 500 employees and more than 500 employees), and the respondent's position (manager/supervisory responsibility employee, non-supervisory responsibility employee) and the sphere of business.

The third part contained the Czech translation of Wallach's questionnaire (1983) - Organizational Culture Index $(\mathrm{OCI})$. OCI describes organizational cultures in three dimensions: bureaucratic, innovative and supportive. The questionnaire consists of 24 items, the four-point Likert scale is used for evaluating answers ranging from 0 (does not describe our organization) to 3 (describes our organization in most cases). Subsequently, the answers were evaluated for the individual dimensions of organizational culture (eight items for each dimension) - the results are not a part of this paper.

The fourth part was devoted to the Czech version of the "Job Satisfaction Questionnaire" (Spector, 1985), which consists of 36 items and was used to measure the perception of the level of job satisfaction. The questionnaire contained nine categories of factors: pay, career growth, supervision, fringe benefits, recognition, working conditions, co-workers, nature of work and communication. Respondents were instructed to determine the extent of their agreement with each item on a six-point scale ranging from "strongly disagree" (1) to "completely agree" (6).

\section{Study limitations}

The research had several limitations. The first limitation is the selection of respondents. This shortcoming is not so crucial because the Czech Republic currently has a relatively 
homogenous socio-economic composition. Another limitation is the fact that the category of employees with a lower level of education was underrepresented in our sample. The method of data collection through distance learning students may also pose a certain limitation (Pudło \& Gavurová, 2012). However, this disadvantage partially eliminates the diversification of jobs held by these students because they worked in various areas of both the private and public/governmental sector.

In spite of these limitations, we are convinced that our data provide results that expand our knowledge of job satisfaction.

\section{Development of Pay and Other Labour Costs}

Labour costs consist primarily of pay and related social security payments. The remaining nonpay costs are considerably lower and thus less visible. It was these costs through which the employers tried to save money during the time of the crisis, after 2008 (CZSO, 2015).

Total labour costs are comprised of direct and indirect costs. Direct costs consist of wages and salaries for work done and of compensation for wages and salaries (compensation for national holidays, for holidays, for obstacles on the part of the employee or the employer). Wages or salaries are paid for work performed in the Czech Republic. Wages are monetary payments and monetary value payments (wages in kind) provided by an employer to an employee for work in the private sector. A salary is a monetary payment provided to employees for their work by employers who remunerate these employees wholly or mainly from public resources (funds from the state budget, other public budgets or from public health insurance). Such employers include the state, a self-governing territorial unit, a state fund or a legal school entity established by the Ministry of Education, Youth and Sports, by a region, municipality or voluntary association of municipalities. Wages and salaries are expressed in gross amounts. Indirect costs consist of social costs, social benefits, staff costs and taxes and subsidies. Social costs consist of statutory social security and other social costs. Company cars for private purposes, housing allowances or meal allowances etc. are included in social benefits. The most significant

\section{Fig. 1: Structure of labour costs in 2013 (in \%)}

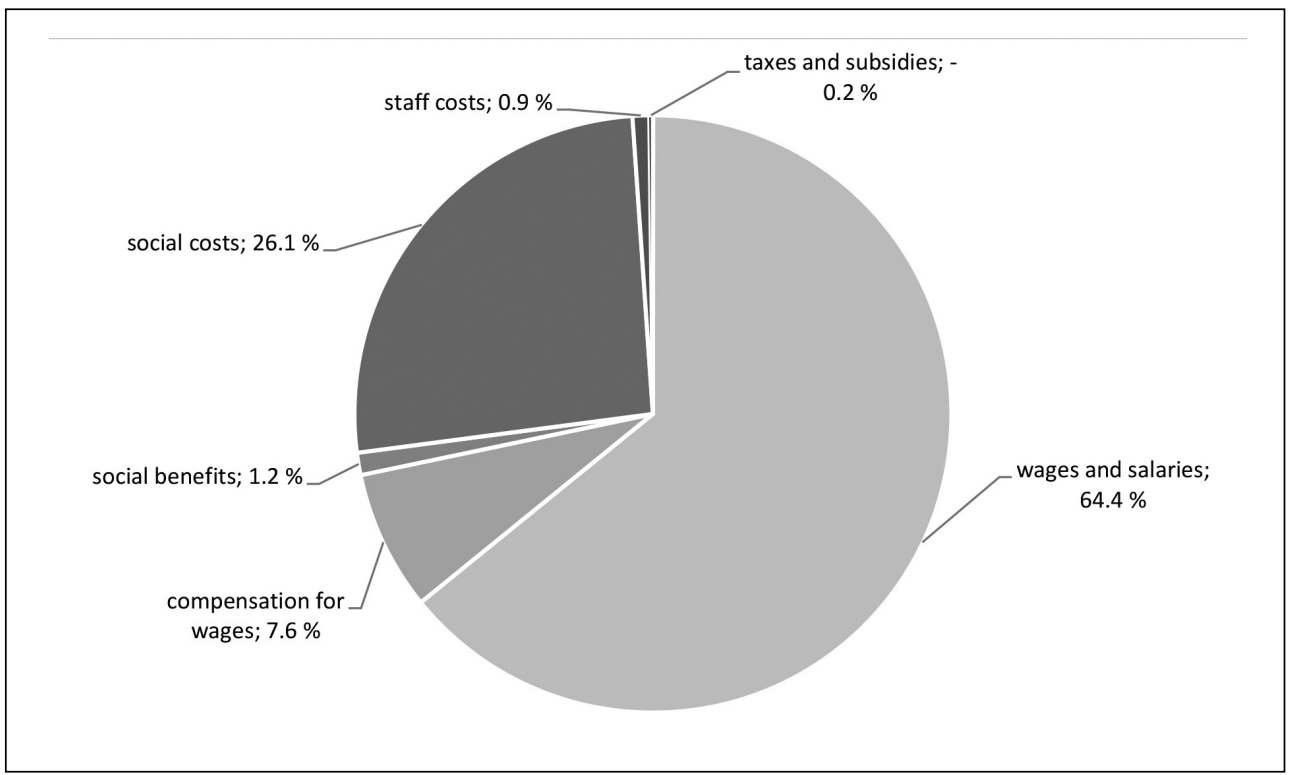


Business Administration and Management

\begin{tabular}{|c|c|c|c|c|c|c|c|c|c|}
\hline \multirow[b]{3}{*}{ Year } & \multicolumn{9}{|c|}{$\begin{array}{l}\text { Labour cost components (CZK/month) per one employee } \\
\text { (recalculated numbers) }\end{array}$} \\
\hline & \multirow[b]{2}{*}{$\begin{array}{l}\text { Labour } \\
\text { costs }\end{array}$} & \multicolumn{3}{|c|}{ Direct costs } & \multicolumn{5}{|c|}{ Indirect costs } \\
\hline & & total & $\begin{array}{l}\text { wages } \\
\text { and } \\
\text { salaries }\end{array}$ & $\begin{array}{c}\text { compensation } \\
\text { for wages }\end{array}$ & total & $\begin{array}{l}\text { social } \\
\text { benefits }\end{array}$ & $\begin{array}{l}\text { social } \\
\text { costs }\end{array}$ & $\begin{array}{l}\text { staff } \\
\text { costs }\end{array}$ & $\begin{array}{l}\text { taxes and } \\
\text { subsidies }\end{array}$ \\
\hline 1994 & 10,244 & 7,240 & 6,546 & 694 & 3,004 & 220 & 2,618 & 169 & -3 \\
\hline 1995 & 12,028 & 8,536 & 7,706 & 830 & 3,492 & 253 & 3,068 & 175 & -4 \\
\hline 1996 & 14,415 & 10,240 & 9,208 & 1,032 & 4,175 & 280 & 3,680 & 224 & -9 \\
\hline 1997 & 15,499 & 11,058 & 9,944 & 1,114 & 4,441 & 289 & 3,956 & 215 & -19 \\
\hline 1998 & 17,014 & 12,170 & 10,969 & 1,201 & 4,844 & 318 & 4,331 & 210 & -15 \\
\hline 1999 & 18,321 & 13,078 & 11,812 & 1,266 & 5,243 & 321 & 4,713 & 221 & -12 \\
\hline 2000 & 19,905 & 14,088 & 12,744 & 1,344 & 5,817 & 334 & 5,240 & 262 & -19 \\
\hline 2001 & 21,777 & 15,330 & 13,791 & 1,539 & 6,447 & 419 & 5,741 & 299 & -12 \\
\hline 2002 & 23,190 & 16,298 & 14,655 & 1,643 & 6,892 & 450 & 6,165 & 303 & -26 \\
\hline 2003 & 24,567 & 17,255 & 15,528 & 1,727 & 7,312 & 475 & 6,522 & 347 & -32 \\
\hline 2004 & 26,428 & 18,597 & 16,722 & 1,875 & 7,831 & 500 & 7,029 & 338 & -36 \\
\hline 2005 & 28,036 & 19,796 & 17,886 & 1,910 & 8,240 & 587 & 7,259 & 424 & -30 \\
\hline 2006 & 28,941 & 20,540 & 18,560 & 1,980 & 8,401 & 561 & 7,513 & 385 & -58 \\
\hline 2007 & 31,020 & 21,854 & 19,594 & 2,260 & 9,166 & 670 & 8,132 & 413 & -49 \\
\hline 2008 & 32,468 & 23,223 & 20,778 & 2,445 & 9,245 & 499 & 8,367 & 421 & -42 \\
\hline 2009 & 32,610 & 23,425 & 20,909 & 2,516 & 9,185 & 472 & 8,425 & 356 & -68 \\
\hline 2010 & 33,275 & 23,904 & 21,459 & 2,445 & 9,371 & 467 & 8,633 & 338 & -67 \\
\hline 2011 & 34,048 & 24,466 & 22,012 & 2,454 & 9,582 & 446 & 8,864 & 331 & -59 \\
\hline 2012 & 34,786 & 25,100 & 22,538 & 2,562 & 9,686 & 424 & 9,004 & 317 & -59 \\
\hline 2013 & 34,825 & 25,055 & 22,417 & 2,638 & 9,770 & 428 & 9,089 & 312 & -59 \\
\hline
\end{tabular}


staff costs include e.g. clothing allowances, contributions towards training and recruitment of new employees. Taxes and subsidies include received subsidies and taxes and sanctions associated with employing people.

The structure of labour costs in 2013 is shown as percentages in the following chart (Fig. 1). Nearly two-thirds (64.4\%) of all labour costs are formed by wages and salaries. Another important item is social costs $(26.1 \%)$ and the third largest item is compensations for wages $(7.6 \%)$.

Over the long term, labour costs have practically remained the same; from 1994-
2013, direct costs ranged between $70-72 \%$, social costs between $25-27 \%$, social benefits between $1-2.5 \%$.

The time series (Tab. 1) shows steady growth in the period from 1994 to 2013, but it slows down in later years. The average monthly labour costs per employee amounted to 10,244 CZK in 1994. Ten years later, in 2004, they equalled $26,428 \mathrm{CZK}$, and in 2013 they equalled 34,825 CZK per employee.

Thus, total labour costs increased by nearly 3.5 times during the monitored period, mainly due to direct costs. The highest amount of growth occurred at the beginning of

\begin{tabular}{|c|c|c|c|c|c|c|c|c|c|}
\hline \multirow[b]{2}{*}{ Period } & \multicolumn{3}{|c|}{ CR total } & \multicolumn{3}{|c|}{ Business sphere } & \multicolumn{3}{|c|}{ Non-business sphere } \\
\hline & $\begin{array}{c}\text { Nominal } \\
\text { wage in } \\
\text { CZK }\end{array}$ & $\begin{array}{c}\text { Nominal } \\
\text { wage index, } \\
\text { CPPY }=100\end{array}$ & $\begin{array}{l}\text { Real wage } \\
\text { index, } \\
C P P Y=100\end{array}$ & $\begin{array}{c}\text { Nominal } \\
\text { wage in } \\
\text { CZK }\end{array}$ & $\begin{array}{c}\text { Nominal } \\
\text { wage index, } \\
C P P Y=100\end{array}$ & $\begin{array}{c}\text { Real wage } \\
\text { index, } \\
\text { CPPY }=100\end{array}$ & $\begin{array}{c}\text { Nominal } \\
\text { wage in } \\
\text { CZK }\end{array}$ & $\begin{array}{c}\text { Nominal } \\
\text { wage index, } \\
\text { CPPY }=100\end{array}$ & $\begin{array}{l}\text { Real wage } \\
\text { index, } \\
\text { CPPY }=100\end{array}$ \\
\hline 2000 & 13,219 & . & . & 13,170 & . & . & 13,457 & . & . \\
\hline 2001 & 14,378 & 108.8 & 103.9 & 14,304 & 108.6 & 103.7 & 14,733 & 109.5 & 104.6 \\
\hline 2002 & 15,524 & 108.0 & 106.1 & 15,380 & 107.5 & 105.6 & 16,197 & 109.9 & 108.0 \\
\hline 2003 & 16,430 & 105.8 & 105.7 & 16,149 & 105.0 & 104.9 & 17,692 & 109.2 & 109.1 \\
\hline 2004 & 17,466 & 106.3 & 103.4 & 17,191 & 106.5 & 103.6 & 18,714 & 105.8 & 102.9 \\
\hline 2005 & 18,344 & 105.0 & 103.0 & 18,019 & 104.8 & 102.8 & 19,877 & 106.2 & 104.2 \\
\hline 2006 & 19,546 & 106.6 & 104.0 & 19,244 & 106.8 & 104.2 & 20,977 & 105.5 & 102.9 \\
\hline 2007 & 20,957 & 107.2 & 104.3 & 20,661 & 107.4 & 104.5 & 22,387 & 106.7 & 103.8 \\
\hline 2008 & 22,592 & 107.8 & 101.4 & 22,439 & 108.6 & 102.2 & 23,334 & 104.2 & 98.0 \\
\hline 2009 & 23,344 & 103.3 & 102.3 & 23,104 & 103.0 & 102.0 & 24,411 & 104.6 & 103.6 \\
\hline 2010 & 23,864 & 102.2 & 100.7 & 23,733 & 102.7 & 101.2 & 24,453 & 100.2 & 98.7 \\
\hline 2011 & 24,455 & 102.5 & 100.6 & 24,447 & 103.0 & 101.1 & 24,494 & 100.2 & 98.3 \\
\hline 2012 & 25,067 & 102.5 & 99.2 & 25,078 & 102.6 & 99.3 & 25,014 & 102.1 & 98.8 \\
\hline 2013 & 25,035 & 99.9 & 98.5 & 24,986 & 99.6 & 98.2 & 25,255 & 101.0 & 99.6 \\
\hline 2014 & 25,607 & 102.3 & 101.9 & 25,546 & 102.2 & 101.8 & 25,879 & 102.5 & 102.1 \\
\hline
\end{tabular}


the period, in 1995 and 1996 (18\% and more). On the contrary, the slowest growth occurred towards the end of the period, in $2009(+0.9 \%)$ and $2010(+2.0 \%)$; in 2013, wages even dropped in comparison with the previous year $(-0.2 \%)$.

In 2008, there was a large drop in social benefits and staff costs within indirect costs. However, their influence was negligible due to their small share of total costs.

The economic crisis manifested itself in the period from 2009 to 2013, when organizations sought to save on optional costs and when staff costs and social benefits dropped.

The time series of total labour costs in the period from 1994 to 2013 showed an average growth rate of $106.7 \%$, which slowed down to $101.4 \%$ in the period from 2009 to 2013 . (CZSO, 2015)

The same trend is seen in the following table (Tab. 2) that tracks average gross monthly wages. 2014 is also shown here when an increase in average gross wages was renewed. This trend should continue according to the current indicators in 2015.

The table of average gross wages (Tab. 2) also shows that differences in gross wages did not differ much in the entrepreneurial and nonentrepreneurial sectors.

On the other hand, very large differences can be seen by sector of activity. These differences are shown in Fig. 2.

Industries with the highest labour costs include, over the long term, "Information and communication" and "Financial and insurance activities" - average labour costs exceed 60,000 CZK per month, but even here, social benefits decreased in 2013 to $83 \%$ of the 2008 level. At the opposite end, well below average, we can find "Accommodation and food service

\section{Fig. 2: Labour costs by sector of activity, 2008-2013 (in CZK)}

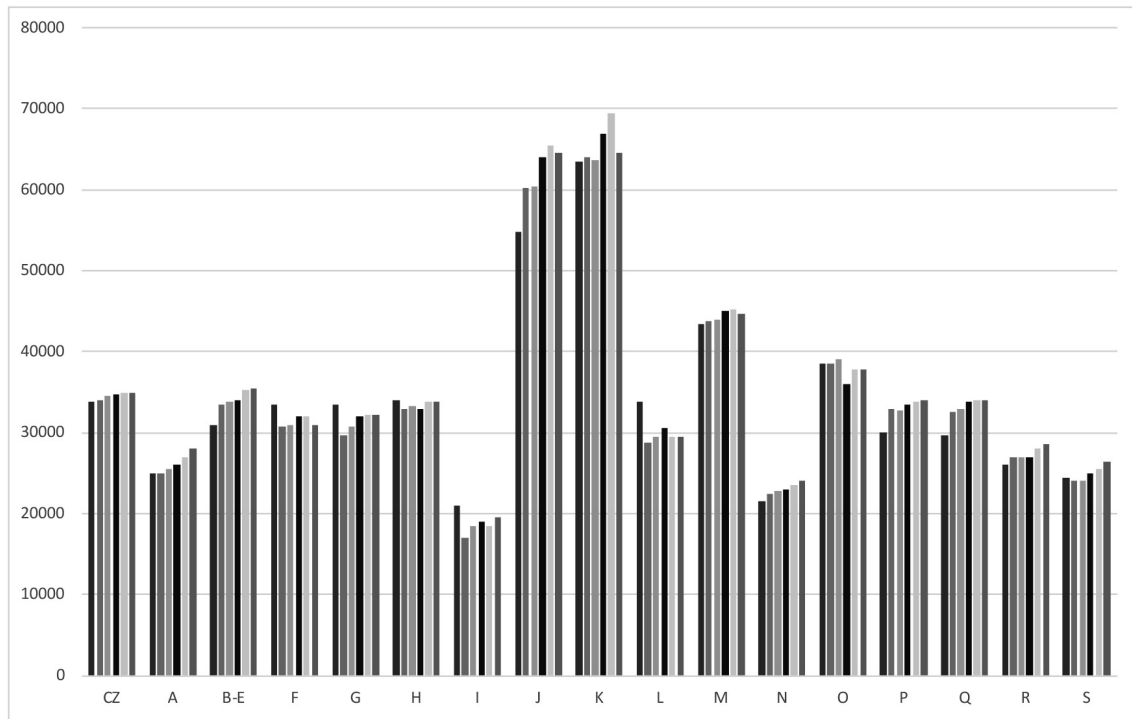

Note: A Agriculture, forrestry and fishing, B-E Total industry, F Construction, G Wholesale and retail trade; repair of motor vehicles and motorcycles, $\mathbf{H}$ Transportation and storage, I Accommodation and food service activities, J Information and communication, K Financial and insurance activities, L Real estate activities, M Professional, scientific and technical activities, $\mathbf{N}$ Administrative and support service activities, $\mathbf{O}$ Public administration and defence; compulsory social security, P Education, Q Human health and social work activities, R Arts, entertainment and recreation, $\mathbf{S}$ Other service activities 


\section{Ekonomika a management}

Tab. 3: Selected characteristics of the examined samples - for 2013 and 2015

\begin{tabular}{|c|c|c|c|c|}
\hline \multirow{2}{*}{ Item } & \multicolumn{2}{|c|}{2013} & \multicolumn{2}{|c|}{2015} \\
\hline & Percentage & Frequency & Percentage & Frequency \\
\hline \multicolumn{5}{|l|}{ Gender } \\
\hline Males & 42.9 & 762 & 42.1 & 619 \\
\hline Females & 57.1 & 1,014 & 57.9 & 851 \\
\hline \multicolumn{5}{|l|}{ Age } \\
\hline Less than 30 & 32.4 & 576 & 32.4 & 476 \\
\hline $30-40$ & 35.2 & 625 & 34.7 & 510 \\
\hline 41 and above & 32.4 & 575 & 32.9 & 484 \\
\hline \multicolumn{5}{|l|}{ Education } \\
\hline Elementary educational level & 1.2 & 22 & 0.7 & 11 \\
\hline Skilled worker & 9.7 & 172 & 6.4 & 94 \\
\hline Secondary school & 42.3 & 752 & 48.8 & 717 \\
\hline Higher professional school & 6.4 & 113 & 6.5 & 96 \\
\hline Undergraduate (distance learning) & 8.2 & 145 & 8.9 & 131 \\
\hline University degree education & 32.2 & 572 & 28.6 & 421 \\
\hline \multicolumn{5}{|l|}{ Years of experience (tenure) } \\
\hline Less than 5 years & 44.0 & 781 & 42.2 & 621 \\
\hline $5-10$ years & 29.5 & 524 & 29.9 & 440 \\
\hline $11-15$ years & 11.9 & 211 & 12.9 & 190 \\
\hline More than 15 years & 14.6 & 260 & 14.9 & 219 \\
\hline \multicolumn{5}{|l|}{ Organization ownership } \\
\hline Czech owner & 42.0 & 746 & 44.5 & 654 \\
\hline Foreign owner & 21.1 & 375 & 21.5 & 316 \\
\hline International corporation & 13.4 & 238 & 14.3 & 210 \\
\hline Public/governmental organization & 23.5 & 417 & 19.7 & 290 \\
\hline \multicolumn{5}{|l|}{ Organization size } \\
\hline up to 50 employees & 35.9 & 637 & 33.3 & 490 \\
\hline up to 250 employees & 30.1 & 535 & 27.9 & 410 \\
\hline up to 500 employees & 9.1 & 161 & 8.2 & 120 \\
\hline more than 500 employees & 24.9 & 443 & 30.6 & 450 \\
\hline \multicolumn{5}{|l|}{ Job level } \\
\hline $\begin{array}{l}\text { Manager/supervisory responsibility } \\
\text { employee }\end{array}$ & 24.4 & 434 & 29.2 & 429 \\
\hline $\begin{array}{l}\text { Non-supervisory responsibility } \\
\text { employee }\end{array}$ & 75.6 & 1,342 & 70.8 & 1,041 \\
\hline
\end{tabular}


activities" and "Administrative and support service activities".

The share of social benefits in total labour costs is only 1.22 to $1.54 \%$. Social benefits declined steadily from 2008 to 2012 from 499 CZK per employee per month down to 424 CZK, which represents a decrease to $85 \%$ of the 2008 level. Only 2013 brought a slight increase to $428 \mathrm{CZK}$; due to increasing wages, their share in total costs is still decreasing. The most important component of social benefits are company cars for private purposes and meal allowances.

\section{Results of the Study Focused on Job Satisfaction in the Czech Republic}

1,776 respondents participated in the study in 2013 and 1,470 respondents participated in the repeated survey (2015). Respondents were aged $17-74$ years and $16-77$ years respectively; their average age was 36.3 years $(S D=10.80)$ and 36.19 years $(S D=10.70)$ respectively. 762 men and 1,014 women participated in 2013, 619 men and 851 women participated in 2015. In both cases they mostly lived in the north-eastern regions of the Czech Republic - the Hradec Králové Region, the Pardubice Region and partially also in the Vysočina Region (the Czech Republic consists of 14 regions). The characteristics of employees and organizations are shown in Tab. 3. It can be seen from these characteristics that both surveys are comparable as far as the examined samples are concerned.

Table 4 presents average values of the satisfaction level of individual determinants of job satisfaction.

The results of this study show that the total job satisfaction level was identical in both researched years (3.73), but the influence of individual determinants on the total satisfaction has changed. The determinants such as promotion, pay, operating conditions and fringe benefits decrease the total job satisfaction level because the average level of these determinants is lower than the average total job satisfaction. On the contrary, the total job satisfaction is increased by other factors such as supervison, coworkers, nature of work and communication, whose average satisfaction is higher than 4.00 .

Despite the same level of the total job satisfaction in both surveys, the level of satisfaction of the analyzed determinants pay and fringe benefits have been increased; in pay the average satisfaction has risen from 3.18 to 3.31 and in fringe benefits it has moderately grown from 3.42 to 3.48 .

Tab. 5 shows the average score of overall job satisfaction as well as the average score of the two selected aspects of job satisfaction pay and fringe benefits - for both surveys.

The results show that overall job satisfaction is still at a very low level, which confirms earlier

\begin{tabular}{|c|c|c|}
\hline 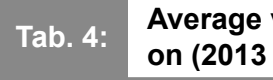 & of inc & f job satisfacti- \\
\hline & 2013 & 2015 \\
\hline Pay & 3.18 & 3.31 \\
\hline Promotion & 2.96 & 3.04 \\
\hline Supervision & 4.25 & 4.27 \\
\hline Fringe Benefits & 3.42 & 3.48 \\
\hline Contingent rewards & 3.45 & 3.53 \\
\hline Operating conditions & 3.35 & 3.26 \\
\hline Coworkers & 4.45 & 4.35 \\
\hline Nature of work & 4.32 & 4.26 \\
\hline Communication & 4.20 & 4.07 \\
\hline Total satisfaction & 3.73 & 3.73 \\
\hline
\end{tabular}




\section{Ekonomika a management}

Tab. 5:

The average score of overall job satisfaction and of the selected aspects of job satisfaction - pay and fringe benefits (2013 and 2015)

\begin{tabular}{|c|c|c|c|c|c|c|}
\hline & \multicolumn{3}{|c|}{2013} & \multicolumn{3}{|c|}{2015} \\
\hline tem & ब্ & 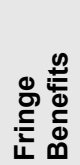 & $=\frac{\frac{c}{0}}{\overline{\frac{\pi}{0}}}$ & ते & 竞 & 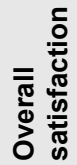 \\
\hline
\end{tabular}

Gender

\begin{tabular}{|c|c|c|c|c|c|c|}
\hline Males & 3.36 & 3.50 & 3.79 & 3.44 & 3.54 & 3.78 \\
\hline Females & 3.05 & 3.35 & 3.69 & 3.21 & 3.44 & 3.70 \\
\hline \multicolumn{7}{|l|}{ Age } \\
\hline Less than 30 & 3.21 & 3.43 & 3.77 & 3.33 & 3.53 & 3.77 \\
\hline $30-40$ & 3.22 & 3.46 & 3.74 & 3.32 & 3.48 & 3.71 \\
\hline $41+$ & 3.12 & 3.35 & 3.68 & 3.27 & 3.45 & 3.71 \\
\hline \multicolumn{7}{|l|}{ Education } \\
\hline Elementary educational level & 3.06 & 3.30 & 3.75 & 2.75 & 3.30 & 3.51 \\
\hline Skilled worker & 3.10 & 3.27 & 3.64 & 2.98 & 3.28 & 3.59 \\
\hline Secondary school & 3.14 & 3.39 & 3.70 & 3.25 & 3.43 & 3.69 \\
\hline Higher professional school & 3.26 & 3.47 & 3.78 & 3.33 & 3.51 & 3.74 \\
\hline Undergraduate (distance learning) & 3.05 & 3.37 & 3.70 & 3.29 & 3.56 & 3.79 \\
\hline University degree education & 3.29 & 3.50 & 3.80 & 3.48 & 3.60 & 3.81 \\
\hline \multicolumn{7}{|l|}{ Years of experience (tenure) } \\
\hline Less than 5 years & 3.22 & 3.47 & 3.79 & 3.37 & 3.54 & 3.80 \\
\hline $5-10$ years & 3.22 & 3.44 & 3.71 & 3.24 & 3.43 & 3.68 \\
\hline $11-15$ years & 3.06 & 3.25 & 3.61 & 3.19 & 3.44 & 3.64 \\
\hline More than 15 years & 3.11 & 3.33 & 3.70 & 3.35 & 3.47 & 3.73 \\
\hline \multicolumn{7}{|l|}{ Organization ownership } \\
\hline Czech owner & 3.17 & 3.39 & 3.74 & 3.36 & 3.43 & 3.79 \\
\hline Foreign owner & 3.41 & 3.58 & 3.82 & 3.45 & 3.68 & 3.80 \\
\hline International corporation & 3.56 & 3.77 & 3.87 & 3.38 & 3.74 & 3.77 \\
\hline Public/governmental organization & 2.79 & 3.11 & 3.56 & 2.97 & 3.22 & 3.49 \\
\hline \multicolumn{7}{|l|}{ Organization size } \\
\hline up to 50 employees & 3.20 & 3.38 & 3.79 & 3.42 & 3.54 & 3.87 \\
\hline up to 250 employees & 3.08 & 3.30 & 3.68 & 3.20 & 3.29 & 3.63 \\
\hline up to 500 employees & 3.11 & 3.50 & 3.73 & 3.25 & 3.45 & 3.68 \\
\hline more than 500 employees & 3.32 & 3.56 & 3.70 & 3.30 & 3.60 & 3.69 \\
\hline \multicolumn{7}{|l|}{ Job level } \\
\hline $\begin{array}{l}\text { Manager/supervisory responsibili- } \\
\text { ty employee }\end{array}$ & 3.53 & 3.64 & 3.91 & 3.60 & 3.64 & 3.85 \\
\hline $\begin{array}{l}\text { Non-supervisory responsibility } \\
\text { employee }\end{array}$ & 3.10 & 3.34 & 3.68 & 3.18 & 3.42 & 3.68 \\
\hline
\end{tabular}


published studies (Franěk \& Večeřa, 2008; Franěk et al., 2014; Medgyesi \& Robert, 2003; Večerník, 2003).

For overall satisfaction, none of the sets of data show significant differences in terms of gender, age, work experience or company size. However, we can see a change in overall job satisfaction for the examined years in cases of education characteristics where the job satisfaction of people with an elementary education significantly decreased (but the sample of people is relatively small); on the other hand, a slight increase of job satisfaction in people studying at universities. Furthermore, overall job satisfaction decreased in people working in multinational corporations and in state, semi-budgetary and budgetary organizations.

As far satisfaction with pay is concerned, the data show that satisfaction with pay slightly increased or remained the same on average. A somewhat significant increase in satisfaction with pay occurred e.g. in the case of women, older people and people with a higher education.

As far as fringe benefits are concerned, a slight increase of satisfaction occurred on average during the examined years.

The average level of satisfaction with fringe benefits is higher than in the case of pay.

\section{Discussion}

The average level of overall job satisfaction is above the average level of satisfaction with pay and fringe benefits with the average level of satisfaction with pay being lower than in the case of fringe benefits. Therefore, one could say that these two determinants reduce the level of overall job satisfaction.

The relatively low level of satisfaction with pay, although the pay level increased during the examined years, may be caused by the significant slowdown in the pay growth rate since 2009. Although pay even dropped in 2013, this fact was not significantly reflected in overall satisfaction according to the survey conducted at the beginning of 2015; on the contrary, satisfaction with pay slightly increased. This may be due to the fact that respondents were happy that slight growth occurred again in 2014.

No significant changes of satisfaction occurred in fringe benefits.

However, this issue can be caused by many other circumstances such as a development of other economic indicators, for example, inflation or a level of unemployment. The key role is also influenced by future expectations of employees who assume that economy will recovery and grow and these expectations are reflected in their attitudes.

For a deeper analysis, it is necessary to evaluate the development of satisfaction over the long term so that a longer time series can be created.

\section{Conclusion}

Pay and fringe benefits are significant factors that affect job satisfaction. The results of the study show that they lower the overall level of job satisfaction since the average level of these determinants is lower than the average level of overall job satisfaction. Overall job satisfaction is increased by other factors, such as supervision, co-workers and the nature of work and communication, whose average level of satisfaction exceeds 4.00. Therefore, the emerging trend of rising pay levels is definitely good for increasing overall job satisfaction. On the other hand, it is impossible to prove that the trends in pay are followed by overall job satisfaction, which is also significantly affected by other factors.

Job satisfaction was examined in the conducted study, where pay, career growth, supervision, fringe benefits, recognition, working conditions, co-workers, nature of work and communication are the key determinants affecting job satisfaction. But is job satisfaction affected only by these factors? Certainly not, because people live in specific communities and that also affects them. On the contrary, job satisfaction is one of the determinants of life satisfaction. Very often, overall life satisfaction, job satisfaction and family satisfaction are analysed as separate phenomena. However, it is obvious that these areas are mutually interconnected and that people who are satisfied in one area of life tend to be satisfied in the other area as well (Williams \& Alliger, 1994). This can be interpreted in two ways: first, a general psychological pessimistic/optimistic disposition, and secondly, that successes/ problems in one area of life are reflected in an evaluation of the other area (Near et al., 1980; Bělík \& Hoferková, 2014). Here we can mention the relationship between job satisfaction and family satisfaction. ISSP data confirm that there is a connection between family satisfaction 
and job satisfaction, even if it is not very strong (a correlation coefficient of 0.30 with statistical significance at a level of 0.01). It is impossible to determine, based on ISSP data, whether job satisfaction is the primary aspect that is then reflected in the positive evaluation of family life, or whether, on the contrary, family life satisfaction is more important, which then positively affects one's perception of work. Hamplová (2004) states in her study that the power of influence may be indicated by two independent regression models. In the first model, family satisfaction is the independent variable while job satisfaction is the explanatory variable. In the second regression model, job satisfaction is the variable being explained, while family life satisfaction is the explanatory variable. Based on these models, we can estimate that if an evaluation of family life deteriorates or improves by one point, job satisfaction will change by 0.36 points. If attitude towards work changes by one point, the evaluation of family life will change by 0.30 points. These conclusions indicate that family life affects professional life more strongly than professional life is reflected in family life.

It would be suitable, within the framework of further surveys, to expand the area of examination to include additional determinants, such as family life satisfaction, or to examine how job satisfaction affects life satisfaction.

The paper was written with the support of the specific project 2016 grant "Determinants affecting job satisfaction" granted by the University of Hradec Králové, Czech Republic.

\section{References}

Bělík, V., \& Hoferková, S. (2014). Přístupy společnosti k rizikovému chování. In $\mathrm{K}$. Janiš ml. (Ed.), Zvládání současných sociálně patologických jevů a rizikového chování: Sborník príspěvků ke 2. ročníku conference (43-50). Opava: Fakulta veřejných politik, Slezská univerzita v Opavě.

Borooah, V.K. (2009), Comparing levels of job satisfaction in the countries of Western and Eastern Europe. International Journal of Manpower, 30(4), 304-325. doi:10.1108/01437720910973025.

Český statistický úrad [CZSO]. (2015). Data týkající se vývoje mezd a zaměstnaneckých benefitú. Retrieved from https://www.czso.cz/.

Chen, J.C., \& Silverthorne, C. (2008). The impact of locus of control on job stress, job performance and job satisfaction in Taiwan. Leadership \& Organization Development Journal, 29(7), 572-582. doi:10.1108/01437730810906326.

Drobnič, S., Beham, B., \& Präg, P. (2010). Good job, good life? Working conditions and quality of life in Europe. Social Indicators Research, 99(2), 205-225. doi:10.1007/s11205010-9586-7.

Eskildsen, J., Kristensen, K., \& Antvor, H.G. (2010). The relationship between job satisfaction and national culture. The TQM Journal, 22(4), 369-378. doi: 10.1108/17542731011053299.

Franěk, M., \& Večeřa, J. (2008). Personal characteristics and job satisfaction. E\&M Ekonomie a Management, 11(4), 63-76.

Franěk,M.,Mohelská,H.,Zubr, V.,Bachmann, P., \& Sokolová, M. (2014). Organizational and sociodemographic determinants of job satisfaction in the Czech Republic. SAGE open. doi:10.1177/2158244014552426.

Hamplová, D. (2004). Životní spokojenost: rodina, práce a další faktory. Praha: Sociologický ústav Akademie věd České republiky.

Judge, T.A., \& Watanabe, S. (1993), Another look at the job satisfaction-life satisfaction relationship. Journal of Applied Psychology, 78(6), 939-948.

Judge, T.A., Thoresen, C.J., Bono, J.E., \& Patton, G.K. (2001). The job satisfaction-job performance relationship: $A$ qualitative and quantitative review. Psychological Bulletin, 127(3), 376-407.

Lange, T. (2009). Attitudes, attributes and institutions:Determiningjobsatisfaction in Central and Eastern Europe. Employee Relations, 31(1), 81-97. doi:10.1108/01425450910916832.

Linz, S.J. (2003). Job satisfaction among Russian workers. International Journal of Manpower, 24(6), 626-652. doi:10.1108/01437720310496139.

Liu, B., Tang, N., \& Zhu, X. (2008). Public service motivation and job satisfaction in China: An investigation of generalisability and instrumentality. International Journal of Manpower, 29(8), 684-699. doi:10.1108/01437720810919297.

Locke, E. (1976). The nature and consequences of job satisfaction. In M.D. Dunette (Ed.), Handbook of Industrial and Organizational Psychology (1297-1349). Chicago (IL): Rand-McNally.

Medgyesi, M., \& Róbert, P. (2003). Satisfaction with work in a European 
perspective: Center and periphery, "Old" and "new" market economies compared. Review of Sociology, 9(1), 43-68. doi: 10.1556/ RevSoc.9.2003.1.3.

Mohelska, H., \& Sokolova, M. (2011). The creation of the qualitative scenarios in the virtual three-dimensional environment second life. Procedia Computer Science, 3(2011), 312315. doi:10.1016/j.procs.2010.12.053.

Mohelska, H., \& Sokolova, M. (2015). Organisational Culture and Leadership - Joint Vessels? Procedia - Social and Behavioral Sciences, 171(January), 1011-1016. doi:10.1016/j.sbspro.2015.01.223.

Near, J.P., Rice, R.W., \& Hunt, R. G. (1980). The Relationship Between Work and Nonwork Domains. The Academy of Management Review, 5(3), 415-429.

Pavelka, T., Skála, M., \& Čadil, J. (2014). Selected issues of the minimum wage in the Czech Republic. E\&M Ekonomie a Management, 17(4), 30-45. doi:10.15240/tul/001/2014-4-003.

Pudło, P, \& Gavurová, B. (2012). Experimental learning in higher education, using simulation games as learning tool. In SGEM 2012: 12th International Multidisciplinary Scientific GeoConference: conference proceedings: Vol. 3: 17-23 June, 2012, Albena, Bulgaria (1093-1100). Sofia: STEF92 Technology Ltd. doi:10.5593/SGEM2012/S23. V3009.

Ryan, R.M., \& Deci, E.L. (2000). Intrinsic and extrinsic motivations: Classic definitions and new directions. Contemporary Educational Psychology, 25(1), 54-67. doi:10.1006/ ceps.1999.1020.

Spector, P.E. (1997). Job satisfaction: Application, assessment, causes, and consequences. Thousand Oaks: Sage.
Šoltés, V., \& Gavurová, B. (2014). Innovation policy as the main accelerator of increasing the competitiveness of small and medium-sized enterprises in Slovakia. In Procedia Economics and Finance: Emerging Markets Queries in Finance and Business: 24-27 October 2013, Tîrgu Mureş, Romania (1478-1485). Amsterdam: Elsevier. doi:10.1016/S22125671(14)00614-5.

Večerník, J. (2003). Skating on thin ice: A comparison of work values and job satisfaction in CEE and EU countries. International Journal of Comparative Sociology, 44(5), 444-471. doi:10.1177/002071520304400502.

Williams, K.J., \& Alliger, G.M. (1994). Role Stressors, Mood Spillover, and Perception of Work-Family Conflict in Employed Parents. Academy of Management Journal, 37(4), 837-868.

doc. Ing. Marcela Sokolová, Ph.D. University of Hradec Králové

Faculty of Informatics and Management Department of Management marcela.sokolova@uhk.cz

doc. Ing. Hana Mohelská, Ph.D. University of Hradec Králové

Faculty of Informatics and Management Department of Management hana.mohelska@uhk.cz

Ing. Václav Zubr University of Hradec Králové Faculty of Informatics and Management Department of Management vaclav.zubr@uhk.cz 


\title{
Abstract
}

\section{PAY AND OFFER OF BENEFITS AS SIGNIFICANT DETERMINANTS OF JOB SATISFACTION - A CASE STUDY IN THE CZECH REPUBLIC}

\author{
Marcela Sokolová, Hana Mohelská, Václav Zubr
}

Emotions are an important factor that affects employee performance; job satisfaction or dissatisfaction represent one of the important components of emotions. There are very few studies dealing with determinants that affect job satisfaction in the Czech Republic. The studies published so far show that the Czech Republic has ranked and still ranks among the states with the lowest level of satisfaction. The aim of this study is to answer the research question whether changing trends in the level of pay and fringe benefits correlates to overall job satisfaction, or satisfaction with pay and fringe benefits. Pay and fringe benefits are significant determinants that affect job satisfaction. The results of the study show that they lower the overall level of job satisfaction since the average level of these determinants is lower than the average level of overall job satisfaction. Overall job satisfaction is increased by other factors, such as supervision, co-workers, nature of work and communication, whose average level of satisfaction exceeds 4.00. Therefore, the emerging trend of rising pay levels is definitely good for increase the level of overall job satisfaction. On the other hand, it is impossible to prove that changing trends in pay correlates to overall job satisfaction, which is also significantly affected by other determinants. It would be suitable, within the framework of further surveys, to expand the area of examination to include additional determinants, such as family life satisfaction, or to examine how job satisfaction affects life satisfaction. The paper was written with the support of the specific project 2016 grant "Determinants affecting job satisfaction" granted by the University of Hradec Králové, Czech Republic.

Key Words: Job satisfaction, pay, fringe benefits, human resources.

JEL Classification: M12.

DOI: 10.15240/tul/001/2016-1-008 